\title{
Solidaarisuutta, huolenpitoa vai pääoman kasaamista
}

ppimisen ohella sosiaalinen on yksi aikalaiskeskustelun muotitermeistä.
Yhteiskunnan ja yhteiskunnallisen relevanssin sijaan aikuiskasvatuksessa on jo vuosikaudet nojattu sosiaalisen konstruktionismin teoriaan ja sosiaalisen oppimisen paradigmaan. Varsinkin vapaata sivistystyötä elähdyttävät opit sosiaalisen pääoman ja sosiaalisten kompetenssien perustavuudesta tieto- ja verkostoyhteiskunnassa selviytymiselle ja menestymiselle.

Quomessa Risto Kangas on eurooppalaisten kollegoidensa tapaan osoittanut Oosiologian ja kansallisvaltion rakentumisen historiallisen vastavuoroisuuden, joka on johtanut yhteiskunnan ja kansallisvaltion voimistuvaan ja itsestään selvään samaistamiseen. Kansallisvaltioyhteiskunnan käsitteessä poliittinen ja taloudellinen julkisuus tulivat ensisijaiseksi. Ihanne yhteiskunnasta moraaliin samaistuvan sosiaalisen normatiivis-kollektiivisena tasona sai alistua ihanteelle, jossa vapaat miehet sivistyneesti ja valistuneesti keskustellen ratkaisisivat politiikan ja talouden suunnan, samalla kun huolenpito ja hoiva on suljettu yksityisyyteen perheiden ja naisten asiaksi. Hyvinvointivaltiossa, etenkin sen pohjoismaisessa mallissa, poliittis-taloudellinen yhteiskuntakäsitys kytki sosiaalisen itseensä uudella tavalla. Yhteiskunta alkoi korvata sosiaalisen, edustaa sosiaalista tai tehdä sosiaalisen - muun muassa universaalin koulutuksen kautta - mahdolliseksi. Raija Julkusen sanoin pohjoismaissa kansallisvaltioista tuli kansallisia "sosiaalisia klubeja" perhe-, ammattiryhmä- tai työmarkkinaperusteisten klubien sijasta.

Q osiaalisen suosio lienee yhteydessä aikakautemme luonteeseen. RanskalaisNetoinen kritiikki perustuu käsitykseen poliittisesta ja sosiaalisesta yhteisenä yliyksilöllisen vastuun ja oikeuksien alueena. Ajassamme on kyse tämän yliyksilöllisen alueen murentumisesta ja korvautumisesta toisiaan edellyttävillä markkinayksilöitymisellä ja strategisella yhteisöllistymisellä (uusheimoistumisella). Suomalaiset sosiaalisen kadottamista koskevat kritiikit ja vastakritiikit kohdistuvat hyvinvointivaltioon. EU:n valtapuheen mukaisesti hyvinvointivaltioksi kehkeytyneen yhteiskunnan väitetään johtaneen kansalaiset passiiviseen riippuvuuteen itsestään ja sosiaalisen vastuun katoamiseen perheistä ja yhteisöistä. Hyvinvointivaltioyhteiskunnan universaalin solidaarisuuden, jakamisen ja tasavertaisuuden sijasta korostetaan aktiivista kansalaisuutta, yksilön omatoimisuutta ja vastuuta työllistymiskykynsä ylläpidosta sekä kolmannen sektorin vahvistamista kansalaisyhteiskunnassa. Myös kriitikot korostavat sosiaalisen kadottamisen poliittista, syrjäyttävää luonnetta. Julkusen tavoin monet toteavat, kuinka uudelleenjärjestäytynyt poliittis-taloudellinen eliitti on kovin helposti omaksunut osallisuuden ansaitsemisen ja pärjäämisen eetoksen, joka näytti jo väistyvän historiaan. John Field epäilee angloamerikkalaisten, sosiaa- 
lisen pääoman oppeihin perustuvien syrjäytymisen vastaisten kasvatusohjelmien siunauksellisuutta. Elleivät ohjelmiin nojaavat "heikot sosiaaliset siteet" kehity odotusten mukaiseen voimakkaaseen sosiaaliseen vastavuoroisuuteen, ohjelmat voivat ajaa yhteiskunnassa heikoimmilla olevia nykyistäkin pahempaan marginaalisuuteen.

un tämän päivän aikuiskasvattajat hakevat sosiaaliselle tulkintoja sosiaa-
lisesta pääomasta, sosiaalisesta oppimisesta ja uusyhteisöllisyydestä, he mieluusti tekevät pesäeroa muinaiseen kansanvalistukseen, jossa suppea eliitti kasvatti rahvasta kelpaavaksi jakamaan kansalaisuutta kanssaan. Vaikka tarinassa on perää, sen kertomistapa vaikuttaa tarkoitushakuiselta. Olihan suomalaisten kansanvalistajien ohjelman tärkeä tavoite aina A. I. Arwidssonista alkaen eliitin, erityisesti sivistyneistön itsensä valistaminen. Kansallisvaltion rakentaminen taloudellisena, ammatillisena, poliittisena ja sivistyksellisenä hankkeena edellytti sosiaalisen rakentamista niin rahvaan kuin eliitin suunnassa. Kuten monet tämän numeron kirjoittajat osoittavat, nykyisen eliitin kansanvalistus perustuu syytöksille: hyvinvointivaltioyhteiskunnan rahvas on ulkoaohjautuvaa ja passiivista, yrittämätöntä ja elää yli varojen tuottavan vientiteollisuuden kustannuksella. Valistus ei näytä sen enempää eliitille kuin sitä kritisoivalle intelligentsiallekaan olevan vastavuoroista ja itsekasvatustakin vain vahvistaessaan sen erityisyyttä. Eliitin on pysyttävänä kovana ja kyettävä asemansa vaatimiin tervehdyttäviin leikkauksiin. Aikuiskasvattajien roolina on rakentaa rahvaassa itsesyyllistymisen mentaliteetti, yksilöllisen markkinoiden arvioinnista ohjautuvan yrittäjäitsen luonnetyyppi. Kriitikon on hyödyllisintä pitäytyä sivistävässä keskustelussa, joka parhaimmillaan saa kiitoksensa median kiinnostuksesta.

osiaalinen lienee historiallisesti saanut niin ihmiskunnalle yhteisiä kuin Nulttuurisesti eriytyneitäkin muotoja. Apinatutkija Frans de Waal arvelee, että ihmisen moraalisuus on lajin kehittämien sosiaalisten taipumusten - kiintymyksen, samaistumisen ja avuliaisuuden - luonnollinen jatko. Kannattaisiko aikuiskasvatusta ja sosiaalista uudelleen ajatellessa perehtyä myös suomalaiseen sosiaalisen perinteeseen, josta aikuiskasvatuksen kanonisoidussa historiassa kerrotaan. Kelpaisiko pohtia vaikka suomalaisten talkoiden merkityksiä angloamerikkalaisten yhteisöllisyysoppien ja EU:n kautta välittyvän aktiivisen kansalaisuuspolitiikan ohella? Ehkä talkoiden metaforalla voisi mobilisoida muutakin kuin suostumuksemme uhrautumiseen ja sosiaalisen äänen vaimentamiseen.

Anja Heikkinen

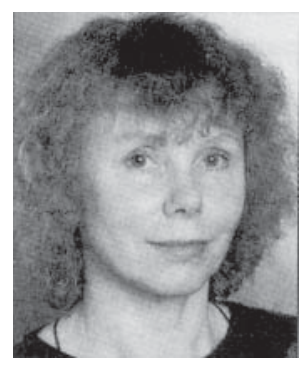

